\title{
クロム酸水溶液中で生成されたアルミニウムアノード 酸化皮膜の構造について
}

\author{
小野 幸子* ・千秋 秀一* ・佐藤 敏彦* \\ Micro-Structure of Anodic Oxide Film on Aluminum formed in Chromic Acid Solution
}

\author{
Sachiko ONO, Shuuichi CHIAKI and Toshihiko SATO
}

The structure of anodic oxide films on aluminum formed in chromic acid solution at constant voltage, and under various electrical or electrolytic conditions, has been studied by electron microscopy. Electron micrographs of film section replica showed that pore branching and subsequent colony structure was formed during anodizing. With film growth, pore colony took hemispherical shape, which resembles to that of barrier layer bottom in typical porous type oxide film, at metal-oxide interface. These film structures were not in accord with vertical structure model proposed by Keller et al. A form of branching pore structure depended on anodizing voltage, the higher the applied voltage, the sooner the initiation of pore branching and colonial structure. The formation of branching colonial structure was strongly favored by following conditions. (1) Sudden voltage drop during anodizing (that is colled Recovery Effect). (2) Anodizing after formation of preliminary thick barrier layer, for instance, primary anodization was done in ammonium tartarate solution. The second anodizing voltage in chromic acid solution was lower than that of preliminary one. The facts suggest that the cause of pore branching is due to the film growth through thick barrier layer.

\section{1. 緒 震}

アルミニウムのアノード酸化皮膜の構造については多 くの研究者によって報告されてきている。多孔質構造に ついては Kellerらの提案した 6 角柱構造 ${ }^{12}$ が多少の修正 を伴って承認されており, 皮膜構造 (孔およびセルのデ ィメンション) と電圧, 電流, 浴温, 浴濃度などの電解 条件との関連が主として硫酸, リン酸, シュウ酸の水溶 液を用いて研究されている1) 。市。こらの研究によれば 孔は皮膜中に規則的に存在し, 地金方向に垂直に延びて いるのであるが，時には孔がねじれたり，接合したり， 枝分かれしたりすることが観察されている2。これらの 現象は非常に興味あるものとされているが5), 詳細につ いては明らかではなく，また，筒状の多孔質モデルでは 説明できないものとしてCsokan ${ }^{6)}$ や Ginsberg, Wefers ら7の報告した繊維状拉よび層状の構造があげられてい $ろ^{8)}$ 。

クロム酸水溶液中で生成されるアノード酸化皮膜の構 造については, Renshaw が酒石酸アンモニウム水溶液 中で電解した後, クロム酸水溶液中で電解して得られた 皮膜の直接透過電子顕微鏡写真から半球体状の孔群（ポ アコロニー）が生成することを確認している9。Rens-

*芝浦工業大学（港区芝浦 3-9-14）

Shibaura Institute of Technology 3-9-14, Shibaura, Minato-ku, Tokyo haw はコロニーが生成するのは 1 次電解による酸化皮膜 の存在によるものと考光, 酸化皮膜の欠陷部分との関連 を中心に論じている。また福田らは皮膜の断面写真から 孔がジグザグ状で複雑な形態をしていると報告している 10)。Ali らはクロム酸水溶液叔よびホウ酸ナトリウム水 溶液中で生成された皮膜の底面のセル構造から，一般的 なセルの他に2次的なセル構造が存在することを述べ11), またクロム酸浴皮膜の断面の電子顕微鏡写真から孔の枝 分かれ群構造 (branching colony structure) を観察し たが，その原因および詳細については考察されていな (12)。

このようにクロム酸浴皮膜の構造は Keller らのモデ ル(vertical pore structure)に対して branching colony pore structure ともいうべきものであるが，孔の枝分か れはアノード酸化中に電圧を降下させた時にも観察され ており 2),13),14)，アノード酸化皮膜生成 反応を考えるら えに打いて興味ある問題と思われた。そこで著者らは定 電圧でアノード酸化して得られたクロム酸浴皮膜の枝分 かれ構造を電子顕微鏡を用いて明らかにし，皮膜生成機 構について検討を行なった。

\section{2. 実 験 方 法}

\section{2-1＼cjkstart試料および雨解条件}

アノード酸化に供する試料は99.5\%のアルミニウム板 $(20 \times 10 \times 0.5 \mathrm{~mm})$ を $70^{\circ} \mathrm{C}$ の $5 \%$ 水酸化ナトリウム水溶 液で脱脂後，30\%硝酸に浸セキし，水洗して用いた。 
電解浴は(1) $3 \mathrm{wt} \%$ クロム酸 $\left(\mathrm{CrO}_{3}\right)$ 水溶液, 浴温 $40 \pm$ $0.5^{\circ} \mathrm{C}$ ，打よび (2) $3 \mathrm{wt} \%$ 酒石酸了ンモニウム水溶夜を用 いた。対極は $99.5 \%$ のルミニウムとし， $500 \mathrm{~m} l$ のビー カー中でカクハンをしながら電解を行なっだ。

アノード酸化は $20 \mathrm{~V}, 40 \mathrm{~V}, 60 \mathrm{~V}, 80 \mathrm{~V}$ の各浴電圧で定電 圧電解を行なった。この時, 電流は $250 \mathrm{~mA} / \mathrm{cm}^{2}$ 以上に ならないよらにあらかじめ設定しておき，電流一時間曲 線をプリボックスを通してペンレコーダに記録した。

\section{2-2 電子顕微鏡観察}

皮膜断面の電子顕微鏡観察のためのレプリカ作成はカ 一ボン抽出レプリカ法を用いた。皮膜一地金界面のセル 構造観察は, 皮膜をりン酸一クロム酸混液中で煮沸し溶 解ハク離後のアルミニウム地金面のカーボン 2 段レプリ カにより行なった。いずれもゲルマニウムでシャドウイ ングを行なった。

\section{3. 実 験 結 果}

\section{3-1 定電圧電解}

$3 \%$ クロ 酸水溶液中で $120 \mathrm{~min}$ 定電圧でアノード酸 化して生成した皮膜の断面の電子顕微鏡写真注) を図 1 に示した。図 1 (a)は 20Vの場合であるが，七ル構造は皮 膜表面に近い部分では地金方向にほぼ垂直に延びている が，電解後期になると（すなわち地金に近い部分）セル はななめに広がるように 放射状になっているのが 観察された。40V電解皮 膜でも同様に表面付近で はほぼ垂直でありそその 後, 扇形に広がったセル 構造がみられる。80V 電 解皮膜では表面付近から 孔が枝分かれを起こして いるのが観察され，皮膜 の成長につれて孔の枝分 かれは1つの中を持っ たポアコロニーとして発 達していくのがわかっ た。このポアコロニーは 皮膜一地金界面に打いて あたかもコロニーが1つ のセルであるかのように 半球体状突出してい る。 $80 \mathrm{~V}$ 電解皮膜に打い

注）皮膜の断面写真はい ずれも上側を表面側, 下側をアルミニウム地 金側としてある。

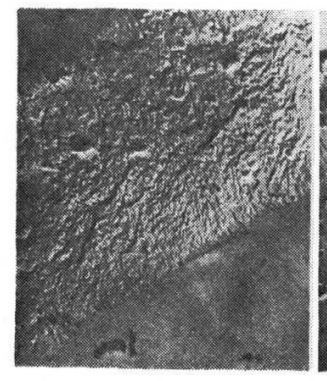

(a) $20 \mathrm{~V}$
てより明らかに観察される枝分かれコロニー構造は本質 的には $20 \mathrm{~V}$ おび $40 \mathrm{~V}$ 電解の皮膜にも共通なものと考兄 られるが，枝分かれの起こりやすさは電圧が高いほど著 しく，したがって枝分かれを開始する時期は電圧が高い ほど早くなり，またコロニーに上る皮膜一地金界面の凹 凸も激しくなることが観察された。各電圧で生成された 皮膜の外観はいずれも不透明灰白色であった。

図 2 は $80 \mathrm{~V} て ゙$ 電解した皮膜の断面のバリヤ層付近であ り，白くみえる孔が枝分かれをして皮膜成長を続けるの が観察される。電子顕微鏡写真からバリヤ層の厚サを測 定すると，80V電解の皮膜で約 $1200 \AA$ であり，これは $15 \AA / \mathrm{V}$ となって通常いわれている多孔質皮膜のパリヤ層 厚サ12,2,15)上り大きかった。

図3は80Vで120 min電解して得られた皮膜を溶解八 ク離した後の地金面のセル跡の電子顕微鏡写真である。 セルの大きさは一様ではなく，またセルの幾つかは，七 ル中に微少なくぼみを持っているのが観察された。これ らのセルは皮膜断面から観察されたようにコロニーを形 成して括り，地金面に半球体状に突出した結果による大 きなへこみるみられる。20V，40V，60V，80Vのそれぞれ の電压で電解した試料の皮膜八ク離面の観察から，七ル およびュロニーの大きさは電圧が高いほど大きいことが 明らかになったが，個々の大きさにはバラッキがあり，

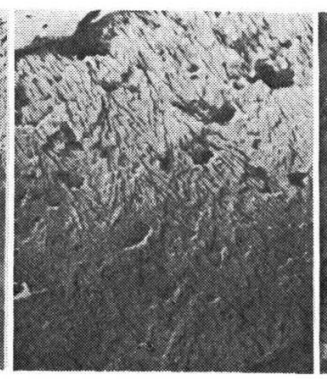

(b) $40 \mathrm{~V}$

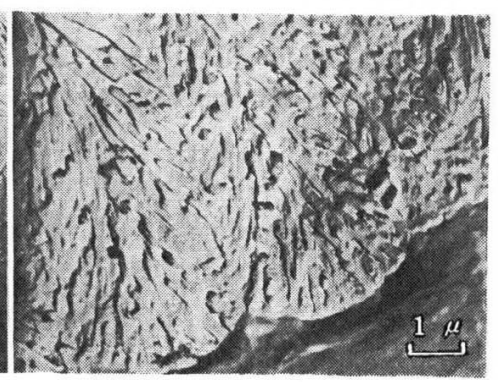

(c) $80 \mathrm{~V}$

Fig. 1 Electron micrographs of cross section of oxide film formed in $3 \%$ chromic acid at various voltage for $120 \mathrm{~min}, 40^{\circ} \mathrm{C}$

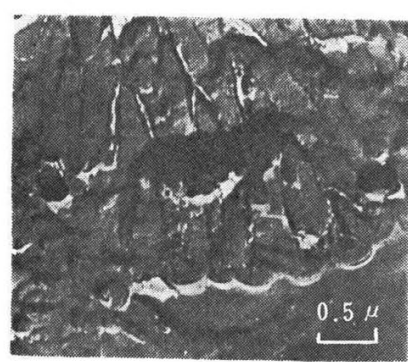

Fig. 2 Electron micrograph of cross section of oxide film showing barrier layer and pore structure

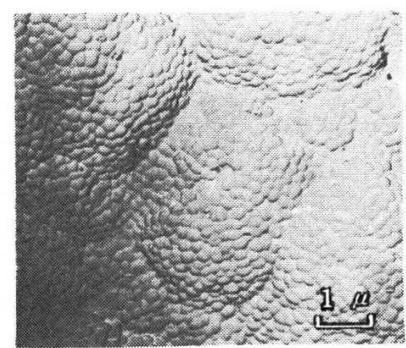

Fig. 3 Electron micrograph of metaloxide interface (metal side) of anodized specimen in $3 \%$ chromic acid for $120 \mathrm{~min}$ at $80 \mathrm{~V}, 40^{\circ} \mathrm{C}$ 


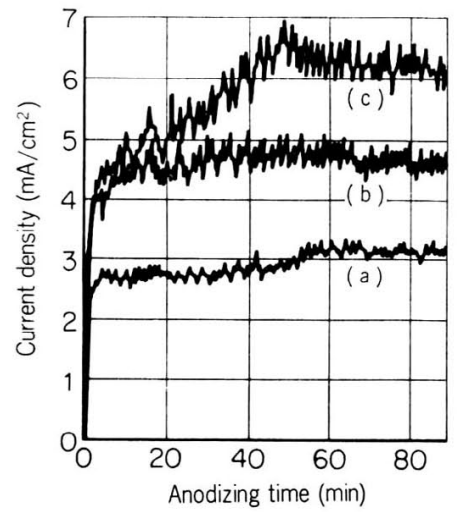

Fig. 4 Current density-time curves at various bath voltage in $3 \%$ chromic acid at $40^{\circ} \mathrm{C}$
(a) $20 \mathrm{~V}$
(b) $40 \mathrm{~V}$
(c) $80 \mathrm{~V}$

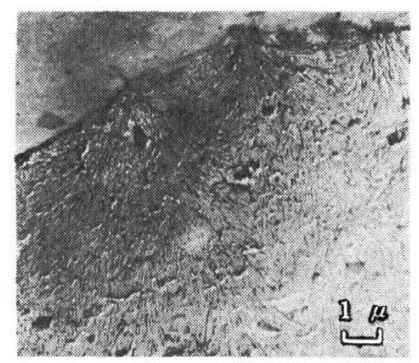

Fig. 5 Electron micrograph of film section. Initial formation at $60 \mathrm{~V}$ in $3 \%$ ammonium tartrate solusion at $20^{\circ} \mathrm{C}$, reanodized at $40 \mathrm{~V}$ in $3 \%$ chromic acid at $40^{\circ} \mathrm{C}$

数式的な関係はつかめなかった。また $80 \mathrm{~V}$ 電解で，アノ 一ド酸化時間を变化させた時のセル構造の変化をみた が，セルは徐々に大きくなっているのが認められ，枝分 かれが進行すると一定電圧の下でもセル径が大きくなる と思われた。

図 4 は定電圧電解における電流一時間曲線である。電 流はいずれの電圧でも著しい振動を伴っており，80V電 解に拈いては $50 \mathrm{~min}$ 後位まで徐々に電流が立り上がり, その後定常となった。定電压に和ける電流，あるいは定

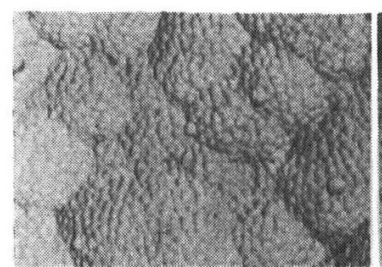

(a) $10 \mathrm{~min}$

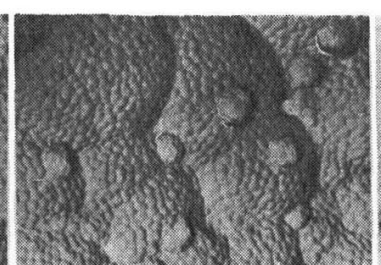

(b) $20 \mathrm{~min}$

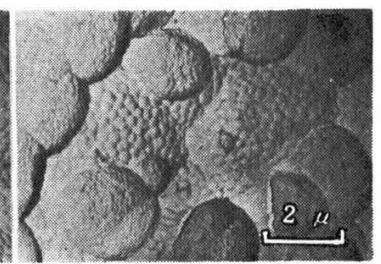

(c) $40 \mathrm{~min}$
Fig. 7 Metal-Oxide interface (metal-side) of anodized specimens at different times after a sudden voltage drop from $80 \mathrm{~V}$ to $40 \mathrm{~V}$ in $3 \%$ chromic acid at $40^{\circ} \mathrm{C}$ (primary anodizing time at $80 \mathrm{~V}: 60 \mathrm{~min}$ )

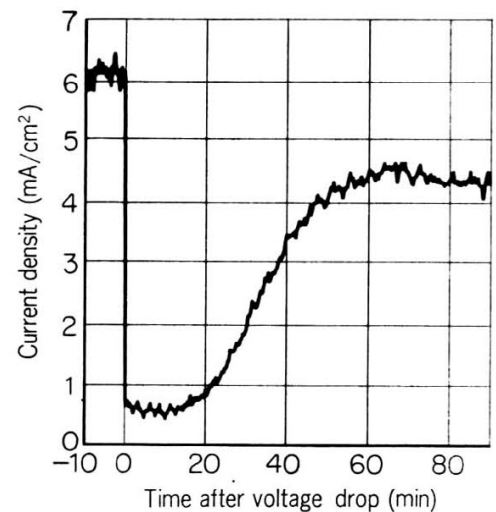

Fig. 6 Current density-time curve obtained on decreasing the voltage from $80 \mathrm{~V}$ to $40 \mathrm{~V}$. Primary anodizing time: $60 \mathrm{~min}$

電流に括ける電圧の振動現象は，一般に皮膜の絶縁破壊 と修復が起こる場合に観察されて扣り，クロム酸水溶液 中での電流の振動現象も同様な原因に上るものと考只ら れる。電流一時間曲線に電流の立ち上がりがみられるの は，皮膜の成長につれポアコロニーが発達し，地金面へ 半球体状に突出した形をとり皮膜一地金 界面面積が増加 するためと考えられる。

\section{3-2 酒石酸アンモニウム浴一クロム酸浴 2 段電解}

クロム酸浴中でアノード酸化して生成した枝分かれ皮 膜では厚いバリヤ層が生成することが明らかになったの で，逆に厚いバリヤ層が存在する場合に皮膜構造はどの ような影響をらけるかについて検討した。1段目として $3 \%$ 酒石酸丁ンモニウム浴中で $40 \mathrm{~V}, 60 \mathrm{~V}, 80 \mathrm{~V}$ の各電圧で $30 \mathrm{~min}$ 電解し, 次に試料を $3 \%$ クロム酸浴に移し $40 \mathrm{~V}$ で再び電解した。1 段目が40Vだった場合の皮膜構造 は, クロム酸浴のみで $40 \mathrm{~V} て ゙$ 電解した皮膜構造（図 1 (b)）と同様であったのに対し，1 段目が60Vでは図 5 K 示したように著しい孔の枝分かれを伴ったポアコロニー の発達が観察された。コロニーは皮膜中で幾分ランダム に分布していた。1 段目が $80 \mathrm{~V}$ の場合も同様に激しい枝 分かれを伴ったコロニー構造がみられた。これらの実験 から厚いバリヤ凮の存在が皮膜の枝分かれコロニー構造 を促進させることが明らか になった。

\section{3-3 アノード酸化時の 浴電圧の降下に伴う皮 膜構造の变化}

3一2に記した 2 段のア， ード酸化を行なった時の電 流一時間曲線は, Murphy らの行なった電解中電圧を 急に降下させた時に現われ るいわゆる回復現象に打け 
る場合 ${ }^{16)}$ とく似たすのであった。そこで，クロム酸水 溶液中でアノード酸化中電圧を降下させた時の皮膜構造 の变化を観察した。図6は80Vで60min電解した後, 電 圧を40Vに降下させた時の電流一時間曲線である。電流 は一度急激に減少するが10 min後には徐々に上昇しはじ め, $60 \mathrm{~min}$ 後にほぼ回復した。電流回復に伴う皮膜構造 の変化を皮膜一地金界面のセル構造からみたのが図 7 で ある。図7 (a)は電圧降下 $10 \mathrm{~min}$ 後であるが, 粒状の小さ なこロニーが80Vのセルの下に発生しているのがみられ る。 $20 \min$ 後にはコロニーはかなり成長し, その数も増 加している。40 min後にはコロニーはかなりの面積を占 めるようになった。

図8は80Vで120minアノード酸化した後,40Vに降下 させ, $90 \mathrm{~min}$ 電解を続けた時の皮膜断面の電子顕微鏡写 真であり,表面および断面それに Al地金までが連続して いる。長時間の電解のために孔は払大されており，表面 では白ぬきにみえる。 $80 \mathrm{~V}$ 皮膜の下から，七ルディメン ションの小さい $40 \mathrm{~V}$ 皮膜が幾つかのコロニーの形で放射 状に枝分かれをしながら成長しているのが観察された。

\section{4. 考察}

クロム酸水溶液中でアノード酸化して生成した皮膜の 断面の電子顕微鏡写真からパリヤ層の厚サが厚いことが わかり，またセル中の微小なくぼみの存在や電流一時間 曲線に振動がみられることからクロム酸皮膜の枝分かれ コロニー構造の生成機構について次のように考える。

パリヤ層が厚く成長して電流の流れが妨害されるよら になると, バリヤ層の弱い部分に電流が集中して絶縁破 壊が起こる。この時の局部的な電流集中がバリヤ層の何 か所かで起こるため, 複数個の新しい孔が発生する。こ れがセル中の微小なくぼみとして観察されると考える。 皮膜の成長が絶縁破壞とその修復によって起こるという 考えは, 硫酸浴皮膜について Zahavi らによって論じら れている17)。枝分かれした孔はそれぞれが電解電圧に対 応したセルの大ささに成長するため，孔は皮膜表面に対 し垂直でなく屈曲しはじめるが，このような現象があら こらで起こり，屈曲したセルのバリヤ層同士が接近する と酸化すべきアルミニウムがなくなるために，それらの 孔は成長を停止して枯れる。枝分かれするにるかかわら ず成長を停止する孔るあるため，孔は生成電圧に応じた セルディメンションを保らながら成長し，その総数はほ ぼ一定に保たれる。電子顕微鏡観察からは枝分かれの進 行によって，セル径はむしろ大きくなることが認められ た。

図 9 に皮膜構造のモデルを示したが，枝分かれは皮膜 の成長につれ，1つの中心を持ったュロニーの形をとっ ている。厚いバリヤ層を通して電流が局部的に集中して 発生したポアコロニーは放射状に枝分かれをしながら延
び,コロニーの端まで延びた孔は隣のコロニーの孔と接 近することにより枯れ，コロニーの中心部から延びた孔 はさらに枝分かれをしながら放射状に広がっていく。 この過程が繰り返され，図９に示すよらな枝分かれコロ ニー構造が生成すると考えた。コロニーの挙動は, 電圧 が高いほどその大きさが大きいことや地金に対し半球体 状に突出するなど，多孔質皮膜の孔の挙動によく似てい る。

次に図 5〜図 8 に示した実験結果から孔の枝分かれの 原因について考察する。アノード酸化中に急に電圧を降 下させて電解を続けた時の皮膜構造の変化として, 孔が 枝分かれを起こすことを O’Sullivan らが観察している 2),13)。彼らはリン酸浴中で実験を行なっているが, 同様 な現象はシュウ酸浴中に打いても観察され, 永山らによ って報告されている(4)。電流の回復現象時に打けるらら たな孔の発生過程について は, 電流の停滞期に化学的 颃よび電気化学的な溶解に よりバリヤ層が十分薄く なると再び電流が流れ孔が 発生すると説明されている 2),14),18),19)が, この場合,

1 段目の電圧に対応するバ リヤ層は溶解されて薄くな っていくが, 降下した 2 段 目の電圧に対応する厚サま で薄くなる前に弱点部に局 部的に電流が集中して流れ るために孔が枝分かれする のではないだろらか。リン 酸浴やシュウ酸浴自体は定 電圧電解に拈いてはバリヤ 層を厚くする作用が少ない ため回復現象に和ける枝分 かれは連続的とはならず， 図8にみられるクロム酸浴

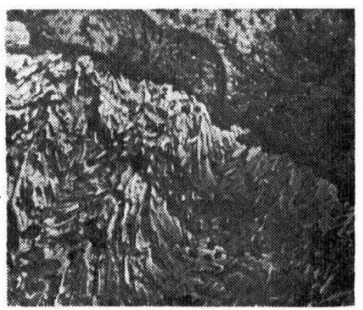

(a)

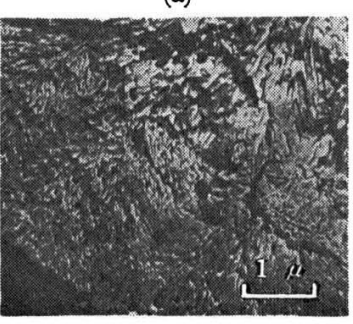

(b)
Fig. 8 Electron micrographs of cross section of oxide film $90 \mathrm{~min}$ after a sudden voltage drop from $80 \mathrm{~V}$ to $40 \mathrm{~V}$ (a) near outer surface (b) nearmetal (primary anodizing time at80V : 120min)

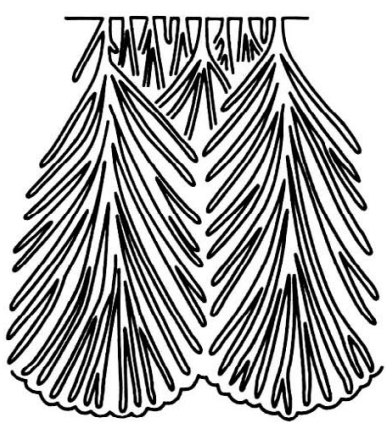

Fig. 9 Schematic model of branching colonial structure 
での場合とは違って，さらに電解を続けると孔は垂直に 発達するのであろう。このような回復現象に括ける孔の 枝分かれや，図5 牤よび図 8 に打いて枝分かれが促進さ れているのがみられることから，厚い:゙リヤ層を通して の電流集中が枝分かれ構造の原因になると考えられる。 クロム酸水溶液中では浴自体が厚いパリヤ層を生成する 作用がある（すなわち，バリヤ層を順調に溶解していく 力が弱い）ために，さらに連続的に枝分かれして特異な 構造を示すのであろら。

従来多くの研究がなされてきたKellerモデル型の多孔 質皮膜に対してクロム酸浴皮膜の枝分かれ構造は非常に 特異なるのではあるが，その生成機構からわかるように クロム酸浴皮膜のみにあらわれるのではなく，バリヤ層 において局部的な電流集中が起こるような条件の下で は出現すると考えられる。たとえばホウ酸ナトリウム浴 皮膜 ${ }^{20)}$, エマタール浴皮膜21)で枝分かれ構造が確認され ている。またCsokan は低温の硫酸水溶液中で生成した 硬質皮膜の構造について, 緎維状および層状の構造を持 ち孔自体すねじれたり曲がったりしていると報告してお $\eta^{6)}$, これは筒状の多孔質モデルの矛盾として Murphy らのコロイドモデル ${ }^{16)} に$ 近いるのとしてとらえられてい るが2),52,6),8)，著者らはこれはクロム酸浴皮膜で観察さ れたものと同様な枝分かれコロニー構造であると考え る。硬質皮膜の構造については，小泉らも“異常層”が 出現すると報告している ${ }^{22)} 。$

アノード酸化皮膜における孔の枝分かれ構造は，この ように多くの場合に見いだされるものであるが，従来論 じられてきた多孔質構造との共通点および相違点につい て,より詳細な研究により明らかにする必要があると思 われる。

\section{5. 結}

\section{論}

クロム酸水溶液中で定電圧でアノード酸化して得られ た皮膜の構造について検討した結果, 次の結論を得た。

（1）皮膜の多孔質構造は孔の枝分かれによるコロニー 構造をとり，コロニ一は皮膜一地金界面で半球体状に突 出する。

（2）コロニーが発達すると皮膜一地金界面で著しい凹 凸が生じ，皮膜の白色化に寄与する。

（3）枝分かれは電解電圧が高いほど発生しやすく，コ ロニーの大きさす大きくなる。

(4) 厚いバリヤ層の存在が枝分かれコロニー構造を促 進させる。 (1975-5-28 受理)

（昭和49年11月，本協会第50回学術講演大会にて発表）

\section{文献}

1) F. Keller, M.S. Hunter, D.L. Robinson; Structural Features of Oxide Coatings on Aluminum, J. Electrochem. Soc., 100, 411 (1953)

2) J.P. O'Sullivan, G.C. Wood; The Morphology and
Mechanism of Formation of Porous Anodic Films on Aluminium, Proc. Roy. Soc. Lond., A 317, 511 (1970)

3) H. Akahori; Electron Microscopic Study of Grow ing Mechanism of Aluminium Anodic Oxide Film, J.Electronmicrosc. Japan, 10,175 (1961)

4) G. C. Wood, J.P. O'Sullivan; The Anodizing of Aluminum in Sulphate Solutions, Electrochim. Acta, 15, 1865 (1970)

5) G.C. Wood; Oxides and Oxide Films Vol. 2, p. 167 (1973, Marcel Dekker. Inc. New York)

6) P. Csokan; Some Observations on the Growth Mechanism of Hard Anodic Oxide Coatings on Aluminium, Trans. Inst. Metal Finish., 41, 51(1964)

7) H. Ginsberg, K. Wefers; Zur Struktur der anodischen Deckschichten auf Aluminiumoberflächen, Metall, 17, 202 (1963)

8 ) J.W. Diggle, T.C. Downie, C.W. Golding; Anodic Oxide Films on Aluminum, Chem. Rev., 69, 1(1969)

9) T.A. Renshaw; A Study of Pore Structures on Anodized Aluminum, J. Electrochem. Soc., 108, 185 (1961)

10）福島敏郎, 福田芳雄, 伊藤伍郎, 中薮和豊; 酸性水 溶液中に打けるアルミニウム陽極酸化皮膜の溶解につ いて, 本誌, 20, 506 (1967)

11) P. Neuteld, H.O. Ali; The Development of Pore and Cellular Structures in Anodic $\mathrm{Al}_{2} \mathrm{O}_{3}$ Films, Trans. Inst. Metal Finish., 48, 175 (1970)

12) H.O. Ali, P. Neufeld; Branching Colony Pore Structure in Anodic Alumina Films, Nature Phys. Sci., 240, [97], 14 (1972)

13) G.C. Wood, J.P. O'Sullivan, B. Vaszko; The Direct Observation of Barrier Layers in Porous Anodic Oxide Film, J. Electrochem. Soc., 115, 618 (1968)

14）永山政一, 高橋英明; アルミニウムの多孔質アノ一 ド酸化皮膜の生成と溶解，日本金属学会会報, 12，449 (1973)

15) M.S. Hunter, P. Fowle; Determination of Barrier Layer Thickness of Anodic Oxide Coatings, J. Electrochem. Soc., 101, 481 (1954)

16) J.F. Murphy, C.E. Michelson; A Theory for the Formation of Anodic Oxide Coatings on Aluminum, Proceedings of Conference on Anodizing Aluminum, Nottingham, 1961 p. 83 (1962, Aluminum Development Association, London)

17) J. Zahavi, M. Metzger; Electron Microscope Study of Breakdown and Repair of Anodic Films on Aluminum, J. Electrochem. Soc., 119, 1479 (1972)

18) J.W. Diggle, J.C. Downie, G.W. Goulding; Processes Involved in Reattainment of Steady-State Conditions for the Anodizing of Aluminum Following Formation Voltage Changes, J. Electrochem. Soc., 116, 737 (1969)

19）志村美知子；アルミニウムのアノード酸化皮膜の構 造と電流の回復効果, 色材, 45, 76 (1972)

20）前田公康, 佐藤敏彦, ホウ酸イオンを含むアルカリ 性浴で形成された酸化皮膜の構造, 芝浦工業大学研究 報告, 19, 133 (1975)

21）小野幸子, 佐藤敏彦; 不透明白色アノード酸化皮膜 の生成について，芝浦工業大学研究報告， 19, 128 (1975)

22）小泉宗栄，上田重朋；アルミニウム硬質陽極酸化皮 膜の異常層に及ぼす材質の影響，本誌，26, 38 (1975) 